\title{
Tax policy and the COVID-19 crisis
}

\section{WP 20/01}

June 2020

\section{Richard Collier, Alice Pirlot and John Vella University of Oxford Centre for Business Taxation}




\title{
Tax policy and the COVID-19 crisis ${ }^{+}$
}

\author{
Richard Collier, Alice Pirlot and John Vella*
}

This article provides some preliminary thoughts on tax policy and the COVID-19 crisis. In the first part, it discusses fiscal measures available to policymakers in response to the COVID-19 crisis. The role of taxation will evolve over the different phases of the pandemic: measures have already been adopted to respond to the crisis in the short-term, but questions remain as to the types of measures that should be adopted in the medium and longer-term. In the second part, this article discusses the current and possible future effects of the pandemic on international tax policy.

Keywords: Covid-19; tax policy; international tax reform; transfer pricing; profit shifting; tax and the digital economy.

\section{Introduction}

This article discusses fiscal measures available to policymakers in response to the COVID-19 crisis. It also offers some preliminary thoughts on the current and possible future effects of the crisis on international business taxation. ${ }^{1}$

Many countries around the world have responded to the COVID-19 crisis through unprecedented lockdowns, severely restricting economic activity as well as the personal movement of their citizens. This has had a devastating effect on economies. Both the IMF and the OECD have estimated that the lockdown will result in significant GDP loss for the period that it remains in place. ${ }^{2}$ At the time of writing it is unclear when lockdowns will be lifted completely. It is likely that they will be lifted in a phased way and that this process will differ from country to country. It is also likely that elements of the lockdown may need to be reinstated before the pandemic is overcome.

Tax policy has an important role to play in alleviating and addressing the negative consequences of the lockdown on the economy. This role will evolve with the different phases of the crisis caused by the pandemic, and the first part of this article sets out and discusses a number of tax policy options in each

\footnotetext{
$\div$ The final version of this paper will be published in Volume 48 of Intertax (Issue 8/9).

*Richard Collier, Associate Fellow at the Oxford University Centre for Business Taxation, richard.collier@sbs.ox.ac.uk; Alice Pirlot, Research Fellow at the Oxford University Centre for Business Taxation, Alice.Pirlot@sbs.ox.ac.uk; John Vella, Associate Professor of Taxation in the Faculty of Law at the University of Oxford and Assistant Director of the Oxford University Centre for Business Taxation, John.Vella@law.ox.ac.uk. 1 Please note that this article has been written with the information available up to the $1^{\text {st }}$ of May 2020. The authors would like to express their thanks to Michael Devereux and all the researchers at the Oxford University Centre for Business Taxation. 2 IMF, World Economic Outlook, The Great Lockdown, Chapter 1 (April 2020), available at https://www.imf.org/en/Publications/WEO/Issues/2020/04/14/weo-april-2020 (accessed 1 May 2020); OECD, Evaluating the initial impact of Covid containment measures on activity, (OECD Publishing, 2020). See also G-20 Surveillance Note, COVID19 - Impact and Policy Considerations, G-20 Finance Ministers and Central Bank Governors' Meetings, (15 April 2020), available at https://www.imf.org/external/np/g20/pdf/2020/041520.pdf (accessed 1 May 2020).
} 
phase. ${ }^{3}$ In the first phase, while the lockdown is in place and countries are experiencing an acute overall disruption, tax measures can help mitigate the impact of the crisis by providing businesses and households with cash flow in order to avoid a complete collapse of the economy. In the second phase, once the lockdown is lifted, businesses and households are likely to require similar economic support measures. Again, tax policy can assist in keeping businesses afloat. However, in this phase, once there is sufficient certainty about the recovery, fiscal policymakers might also consider introducing incentives to stimulate demand and re-establish supply chains. In the third phase, the longer term, tax policy will turn back to its traditional primary objective, namely the generation of revenue. Indeed, once the crisis is over, it is likely that tax will play a key role in offsetting the costs of the crisis.

In the second part of this article the focus narrows to international business taxation, as the crisis comes at a critical juncture in the history of the international tax system. The 137 member countries and jurisdictions of the Inclusive Framework are currently discussing fundamental and unprecedented reform of the system, and the time for taking final decisions on new and momentous policy directions is fast approaching. Pressure to reach multilateral agreement is high, not least because of wide-spread public and political demand for reform and the growing threat of unilateral action by countries. Against that background, this article asks whether the crisis has provided any further lessons about the existing tax system and reflects on how it may impact the international policy debate at this delicate time.

The article proceeds as follows. Section II analyses tax measures that have already been introduced in Phase I of the crisis and measures that have been proposed for Phases 2 and 3 . Section III considers a number of issues created by the crisis which impact elements of the existing international tax system and then reflects on the impact the crisis may have on the broader policy debate as the time for major decisions about the system approaches. Section IV concludes.

\section{Tax policy responses to the COVID-19 crisis}

\section{Phase I: short-term tax responses}

Various economic support measures, including tax measures, have already been adopted as a first, short-term, response to the COVID-19 crisis. The objective of this section is not to provide an exhaustive list of all these different measures. Such analyses have already been published elsewhere and an extensive overview of the measures that have been taken so far is available on the OECD website. ${ }^{4}$ Instead, this section classifies these measures into four main categories. This highlights the fact that fiscal responses have primarily addressed four main objectives: boosting cash flow, influencing behaviour, supporting health action and providing legal certainty. ${ }^{5}$

\footnotetext{
3 The classification in three phrases draws on that of A. Bénassy-Quére et al., COVID-19: Europe needs a catastrophe relief plan, (11 March 2020), available at https://voxeu.org/article/covid-19-europe-needs-catastrophe-relief-plan (accessed 1 May 2020).

${ }^{4}$ See the database ("Tax policy measures taken so far") on OECD, Tackling Coronavirus (COVID-19): contribution to a global effort, available at http://www.oecd.org/tax/tax-policy/ (accessed 1 May 2020). See also J. Rogers-Glabush \& T. Morales, Emergency Tax Measures in Response to the COVID-19 Pandemic 60 European Taxation 7 (2020). See also, the IMF, Policy responses to COVID-19, Policy Tracker, available at https://www.imf.org/en/Topics/imf-and-covid19/Policy-Responses-toCOVID-19 (accessed 1 May 2020).

${ }^{5}$ Other criteria could be used to classify the short-term tax responses to the crisis. For examples, measures could be divided on the basis of their fiscal or non-fiscal nature, their direct or indirect tax nature or based on the timing of their adoption. See, for example, the fivefold classification used by the OECD (OECD, Tax and Fiscal Policy in Response to the Coronavirus Crisis: Strengthening Confidence and Resilience (OECD Publishing, 2020), at p. 12, available at https://www.oecd.org/tax/taxpolicy/tax-and-fiscal-policy-in-response-to-the-coronavirus-crisis-strengthening-confidence-and-resilience.htm (accessed 1
} 
A first category includes domestic measures aimed at boosting cash flow, either directly via the allocation of lump-sum subsidies and/or government guarantees for business loans or indirectly via the tax system. These measures can be used to support households as well as businesses. From a tax perspective, three subcategories of measures have been adopted by countries.

First, many countries have introduced measures that modify the temporal application of the tax system with a view to helping alleviate cash-flow pressure for businesses. Generally speaking, these measures apply to all businesses. For example, most countries have allowed the deferral of the payment of certain taxes, such as corporate income tax (CIT) or value added tax (VAT). Some countries have also waived or lowered interest rates on late payments and/or speeded up tax refunds. In the UK, for example, a range of such measures has been introduced: the deferral of VAT payments, the deferral of income tax payments for the self-employed to January 2021 (instead of July 2020), the freezing of late payment penalties and interest in case of deferral, and the use of the HMRC time to pay service for businesses and the self-employed in financial distress. ${ }^{6}$

Second, some countries have introduced more radical measures that exempt businesses from paying part of their usual tax bill. Generally, these measures apply only to specific sectors that are deemed to be particularly affected by the crisis. For example, the UK has introduced a business rates holiday for the retail, hospitality and leisure sectors. ${ }^{7}$ On the upside, the targeted scope of such measures indicates that the government is trying to support the businesses that need it the most. On the downside, some businesses might fall out of the scope of this tax benefit, despite their need for economic support.

Third, some countries have relaxed the conditions that apply to the application of some favourable tax provisions. For example, some countries have introduced more generous provisions with regard to the carry forward (or back) of losses. ${ }^{8}$ Some other countries, such as the UK, have relaxed the conditions on non-taxable business expenses for employees working from home, which arguably facilitates the transition to homeworking by limiting related costs. ${ }^{9}$

\footnotetext{
May 2020), and following. See also the IMF report that distinguishes between "spending-side measures", "revenue-side measures" and "government-supported liquidity measures": IMF, Fiscal Monitor: Policies to Support People During the COVID-10 Pandemic, (April 2020), pp. 17-18.

${ }^{6}$ These measures, as well as other countries' measures, are listed in CIAT/IOTA/OECD, Tax Administration Responses to COVID-19: Measures Taken to Support Taxpayers, (21 April 2020), available at https://www.oecd.org/coronavirus/policyresponses/tax-administration-responses-to-covid-19-measures-taken-to-support-taxpayers/ (accessed 1 May 2020). See also UK, Financial support for businesses during coronavirus (COVID-19), (3 April 2020) available at https://www.gov.uk/government/collections/financial-support-for-businesses-during-coronavirus-covid-19\#paying-tax (accessed 1 May 2020).

7 See the UK Government, Financial support for businesses during coronavirus (COVID-19) (3 April 2020), available at https://www.gov.uk/government/publications/guidance-to-employers-and-businesses-about-covid-19/covid-19-supportfor-businesses (accessed 1 May 2020). Similar measures apply in Northern Ireland, Scotland and Wales. See also, in England, UK Guidance, Check if your nursery is eligible for business rates relief due to coronavirus (COVID-19) (22 March 2020), available at https://www.gov.uk/guidance/check-if-your-nursery-is-eligible-for-business-rates-relief-due-to-coronavirus-covid-19 (accessed 1 May 2020). For Scotland, see UK, The Non-Domestic Rates (Coronavirus Reliefs) (Scotland) Regulations 2020, available at http://www.legislation.gov.uk/ssi/2020/101/contents/made (accessed 1 May 2020).

${ }^{8}$ See the countries with "enhanced loss offset provisions" in the OECD database, supra n. 4.

${ }^{9}$ See the UK Guidance, Check which expenses are taxable if your employee works from home due to coronavirus (COVID-19), (26 March 2020), available at https://www.gov.uk/guidance/check-which-expenses-are-taxable-if-your-employee-worksfrom-home-due-to-coronavirus-covid-19 (accessed 1 May 2020).
} 
Some countries have suggested that aid measures to alleviate the economic consequences of the pandemic should be denied to companies that rely on tax avoidance strategies. For example, Denmark has announced that companies that are registered in jurisdictions mentioned on the EU list of "noncooperative jurisdictions" should not get access to the COVID-19 aid measures. ${ }^{10}$ France announced a similar measure but it is unclear whether and how the rule will be applied in practice. ${ }^{11}$ Further detail would be required to make informed comment on these proposals and we thus limit ourselves to some general comments here. The underlying rationale for these measures appears to be that of denying assistance to companies that do not pay their "fair share of tax". ${ }^{12}$ But imposing sanctions with potentially very significant consequence on companies for having engaged in planning activity which while potentially aggressive - still falls within the ambit of the law is problematic for a number of reasons, especially where the application of any particular test leaves significant discretion to state authorities. First, there are the legal fundamentals: The rule of law broadly requires that taxpayers are taxed according to the law as enacted by the legislature and - if in doubt - interpreted by the judiciary. ${ }^{13}$ Second, there may be various practical problems to contend with, in some instances linked to the underlying conceptual problem of defining the ambit of the "avoidance" that is to be targeted. Countries seeking to combat the avoidance problem through swiftly-enacted and ad hoc populist measures may find it difficult to achieve their objectives. In particular, identifying companies that pay less than their "fair share" is - at best - challenging, because the concept is amorphous. Tying such measures to lists of tax havens may appear to be a convenient solution but it is likely to prove problematic. For a start, these lists, including the one produced by the EU, are notoriously flawed. ${ }^{14}$ Furthermore, while generally indicative of aggressive tax planning behaviour, the use of tax havens is not necessarily conclusive evidence even of this kind of planning in every single case. Finally, even if there was clear evidence of aggressive tax planning through the use of tax havens, it is not clear why a company using this type of planning should be treated differently to one using other planning

\footnotetext{
${ }^{10}$ See IBFD, tax news, Denmark, COVID-19 Pandemic: Emergency Tax Measures Banned for Tax Haven Companies and Profit Distributions.

${ }^{11}$ For Denmark, see A. Colon, Denmark Nixes COVID-19 Relief for Companies in Tax Havens, Tax Notes (20 April 2020), available at https://www.taxnotes.com/featured-news/denmark-nixes-covid-19-relief-companies-taxhavens/2020/04/20/2cfpp (accessed 1 May 2020). For France, see L. Saint-Martin et A. de Montgolfier, Rapport fait au nom de la Commission mixte paritaire chargée de proposer un texte sur les dispositions restante $n$ discussion du projet de loi de finances rectificative pour 2020, (23 April 2020), available at http://www.assembleenationale.fr/dyn/15/rapports/2820/115b2832 rapport-fond (accessed 1 May 2020). See also the European Parliament, Resolution on EU coordinated action to combat the COVID-19 pandemic and its consequences, (2020/2616(RSP)) (17 April 2020), available at https://www.europarl.europa.eu/doceo/document/TA-9-2020-0054 EN.html (accessed 1 May 2020). Note that this resolution refers to "tax evasion" and not tax avoidance: the European Parliament "insists that the EU institutions and the Member States ensure that public financial support provided to firms in order to combat the economic effects of COVID-19 is conditional upon the funding being used to benefit employees and the recipient firms refraining from bonuses to the management, tax evasion, paying out dividends or offering share buy-back schemes for as long as they receive such support" (para. 34).

12 See J. Thacker, Tax Justice in a Time of Crisis,_(27 April 2020), Church action for Tax justice, available at https://www.catj.org.uk/blog/april-27th-2020 (accessed 1 May 2020); M. Hodge, Companies who avoid tax in good times shoudn't get bailouts now, (28 April 2020), The Times UK, available at https://www.thetimes.co.uk/article/companies-whoavoid-tax-in-good-times-shouldnt-get-bailouts-now-k9117h2jh (accessed 1 May 2020). See also the many reference to the "fair share of tax" during the second reading (House of Commons), Finance Bill 2019-21 (27 April 2020) available at https://services.parliament.uk/bills/2019-21/finance.html (accessed 1 May 2020) and the question of Lord Berkeley to ask her Majesty's Government what plans they have to make it a condition for any company in receipt of state support as a result of COVID-19 to agree to not participate in any artificial tax avoidance arrangements, (29 April 2020), available at https://lordsbusiness. parliament.uk

${ }^{13}$ Moreover, under EU law, such measures could violate the fundamental freedoms, in particular the free movement of capital provisions.

${ }^{14}$ By any measure the use of such a simple listing is likely to prove a relatively crude assessment mechanism. Further, the use of such lists is often criticised as involving political rather than tax technical factors.
} 
strategies, including purely domestic tax planning. Therefore, while it is perfectly understandable that in an economic crisis there will be a refocussing on the need to combat tax avoidance, ${ }^{15}$ this should be done through considered and effective reform of the tax system, rather than through ad hoc populist reform which may well ultimately fail to hit its target and also impact "innocent" employees who have nothing to do with the tax planning activities of their employer.

Aside from the lists on tax havens, other proxies have been used to create linkages between the allocation of benefits and the payment of tax contributions. ${ }^{16}$ For example, some countries calculate benefits as a percentage of the taxable income that has been declared over past years. ${ }^{17}$ Moreover, when they are taxable, benefits will automatically be linked to the tax system which, under progressive tax systems, allows differentiation between taxpayers. ${ }^{18}$

A second category of domestic measures includes measures that are designed to influence behaviour. Many countries have adopted non-fiscal measures aimed at encouraging businesses to "furlough" their employees (which involves creating a temporary leave of absence arrangement rather than laying them off). These measures vary from the adoption of more flexible labour law provisions to the introduction of temporary income support measures. For example, in the UK, the Coronavirus Job Retention Scheme provides a wage subsidy that covers $80 \%$ of the wage costs of furloughed employees, up to $£ 2,500$, for up to 3 months. ${ }^{19}$ Such conditional measures might be more suitable than unconditional lump-sum subsidies as they provide incentives to business not to lay off (i.e. terminate the employment of) employees. ${ }^{20}$ In addition to these measures focused on employment, a few countries have also adopted tax measures aimed at encouraging investment and consumption, such as reduced VAT rates and accelerated capital allowances. ${ }^{21}$ These measures might not be suitable in the first phase of the crisis as the lockdown might not allow demand to be boosted and functioning supply-chains to be re-established. ${ }^{22}$

\footnotetext{
${ }^{15}$ It seems clear that despite the changes brought about by the BEPS project and related initiatives, the international business tax system remains susceptible to avoidance.

${ }^{16}$ Moreover, such use of linkages is not limited to the payment of taxes: the allocation of benefits can be made conditional on other policy objectives. For example, crisis support measures could be made conditional on a commitment to reduce carbon emissions, as suggested by the IMF Fiscal Affairs Department. See IMF, Fiscal Affairs Department, Greening the Recovery, Special Series on Fiscal Policies to Respond to COVID-19 (20 April 2020), available at https://www.imf.org/en/Publications/SPROLLs/covid19-special-notes (accessed 1 May 2020).

17 For example, in the UK, self-employed are allowed to claim a taxable grant if they have lost income due to coronavirus. See the UK Guidance, Check if you can claim a grant through the Self-employment Income Support Scheme, (26 March 2020), available at https://www.gov.uk/guidance/claim-a-grant-through-the-coronavirus-covid-19-self-employment-incomesupport-scheme (accessed 1 May 2020).

${ }^{18}$ Along this line, see D. Marron, If We Give Everybody Cash to Boost the Coronavirus Economy, Let's Tax It, Tax Policy Center (18 March 2020), available at https://www.taxpolicycenter.org/taxvox/if-we-give-everybody-cash-boost-coronaviruseconomy-lets-tax-it (accessed 1 May 2020). See also G. Mankiw, A Proposal for Social Insurance During the Pandemic, (23 March 2020), available at http://gregmankiw.blogspot.com/2020/03/a-proposal-for-social-insurance-during.html (accessed 1 May 2020).

${ }^{19}$ See the UK Guidance, Check if you can claim for your employees' wages through the Coronavirus Job Retention Scheme, (26 March 2020), available at https://www.gov.uk/guidance/claim-for-wage-costs-through-the-coronavirus-job-retentionscheme (accessed 1 May 2020).

${ }^{20}$ See M. Devereux et al. Discretionary Fiscal Responses to the Covid-19 Pandemic, Oxford Review of Economic Policy, forthcoming.

${ }^{21}$ See the countries with "accelerate or enhanced tax depreciation provisions" and those with tax policy measures to "support consumption" mentioned in the OECD database, supra n. 4. See also OECD, Tax and Fiscal Policy in Response to the Coronavirus Crisis, supra n. 5.

22 See M. Harding and H. Simon, Consumption tax revenues under COVID-19: Lessons from the 2008 global financial crisis, OECD paper series on tackling the COVID-19, available at https://www.oecd-forum.org/badges/1420-tackling-covid-19 (accessed 1 May 2020). See also Devereux et al., supra n. 20.
} 
A third category of domestic tax measures includes ad hoc measures that are directly targeted at supporting health priorities by discouraging contact between people and/or facilitating the trade of essential products. ${ }^{23}$ In other words, these measures are aimed at preventing the tax system from becoming an obstacle to the mitigation of the health crisis. For example, in the UK, the duties and VAT on vital medical imports have been lifted, which should facilitate the supply of necessary medical equipment. ${ }^{24}$ Similarly, the previously-imposed charge on the use of plastic bags is no longer obligatory for online grocery shopping, which is supposed to reduce risks of contamination and speed up deliveries in order to minimize the need for people to visit grocery shops. ${ }^{25}$

A fourth category includes measures aimed at providing legal certainty, for example in the application of double tax treaties in a context where the mobility of taxpayers has been significantly limited. In this regard, guidance has already been issued by the OECD. ${ }^{26}$ The OECD guidance is largely concerned with the implications for double tax treaties of the abrupt and dramatic change in where people work and so covers the relevant impact on: the creation of permanent establishments; the residence of companies; the position of cross-border workers; and the residence status of individuals. The range of issues raised (and the various treaty articles that are potentially affected) emphasizes the relevance of people location issues in the context of double tax treaties. ${ }^{27}$ Such issues are often highly significant in their impact. For example, the residence test, which in some cases may be determined by assessing the location of the central management and control or the location of effective management of a company, goes to the heart of how taxing rights may be applied and whether treaty benefits are

${ }^{23}$ See IMF, Fiscal affairs Department, Tax Issues: An Overview, Targeted tax measures can immediately support health priorities, protect individuals and solvent enterprises, and safeguard revenue for the future, (6 April 2020), available at https://www.imf.org/en/Publications/SPROLLs/covid19-special-notes (accessed 1 May 2020).

24 UK News story, Chancellor waives duties and VAT on vital medical imports, (31 March 2020), available at https://www.gov.uk/government/news/chancellor-waives-duties-and-vat-on-vital-medical-imports (accessed 1 May 2020). See also WTO, IMF and WTO heads call for lifting trade restrictions on medical supplies and food, (24 April 2020), available at https://www.wto.org/english/news e/news20 e/igo 15apr20 e.htm (accessed 1 May 2020). At the EU level, see European Commission, Decision of 3 April 2020 on relief from import duties and VAT exemption on importation granted for goods needed to combat the effects of the COVID-19 outbreak during 2020, C(2020) 2146 final (3 April 2020).

25 See UK Policy paper, Carrier bags: why there's a charge, (Updated 19 March 2020), available at https://www.gov.uk/government/publications/single-use-plastic-carrier-bags-why-were-introducing-the-charge/carrier-

bags-why-theres-a-5p-charge (accessed 1 May 2020). Please note that this measure does not qualify as a tax as the charge is not paid to the Revenue.

${ }^{26}$ See the OECD, OECD Secretariat Analysis of Tax Treaties and the Impact of the COVID-19 Crisis, (3 April 2020), available at https://read.oecd-ilibrary.org/view/?ref=127 127237-vsdagpp2t3\&title=OECD-Secretariat-analysis-of-tax-treaties-and-theimpact-of-the-COVID-19-Crisis (accessed 1 May 2020). See also the OECD's The Forum Network webpage, OECD, OECD issues recommendations on implications of the COVID-19 crisis on cross-border workers and other related cross-border matters available at https://www.oecd-forum.org/users/369395-pascal-saint-amans/posts/65032-oecd-issues-recommendationson-implications-of-the-covid-19-crisis-on-cross-border-workers-and-other-related-cross-border-matters laccessed 1 May 2020).

27 See S. Padhi, COVID-19: Forced Residency and Unintended Tax Consequences in Times of a Lockdown, Kluwer International Tax Blog, (9 April 2020), available at http://kluwertaxblog.com/2020/04/09/covid-19-forced-residency-and-unintended-taxconsequences-in-times-of-a-lockdown/?doing wp cron=1587572215.3586330413818359375000 (accessed 1 May 2020 ); J. Schwarz, Lockdown and Tax Treaty Issues, (6 April 2020), Kluwer International Tax Blog, http://kluwertaxblog.com/2020/04/06/lockdown-and-tax-treaty-issues/ (accessed 1 May 2020); J. Schwarz, Transfer Pricing and the Corona pandemic, (22 April 2020), available at http://kluwertaxblog.com/2020/04/22/transfer-pricing-and-thecorona-pandemic/?doing wp cron=1587571921.0904469490051269531250 (accessed 1 May 2020); B. Jones \& K. Nathwani, Where do I lay my hat? 4739 Taxation (2020), https://www.taxation.co.uk/articles/implications-of-covid-19-measures-ontax-residence-and-permanent-establishment (accessed 1 May 2020); D. Weber, The Influence of the COVID-19 Pandemic on the Application of the OECD PPT, GAARs and (Some) SAARs: Lack of Substance for the Protection of Health, (30 April 2020), available at http://kluwertaxblog.com/2020/04/30/the-influence-of-the-covid-19-pandemic-on-the-application-of-theoecd-ppt-gaars-and-some-saars-lack-of-substance-for-the-protection-of-health/ (accessed 1 May 2020). 
available in any particular case. People location issues will similarly often have a major impact in the allocation of profits under a double tax treaty. In the context of profit attribution under Article 7 of the OECD Model for example, the location of the individual key decision makers in the business is often the major factor in determining the allocation of profits as between one state and another. Some countries have also already issued guidance relevant to the interpretation of tax treaties, including in relation to the treatment of frontier workers, the operation of residence or effective management tests and permanent establishment threshold tests. ${ }^{28}$ We comment further on these treaty-related issues in Section III below.

\section{Phase 2: Recovery period}

Phase 2 of the crisis corresponds to the recovery period, which will start at the end of the severe restrictions and is likely to open the path to a slow economic recovery. ${ }^{29}$ In the absence of government support, this period is expected to be characterized by significant uncertainty and financial constraints for businesses. This is likely to lead to higher unemployment and limited long-term investment. Consequently, governments may consider the adoption of support measures, including tax incentives, to support the economic recovery in the long term.

First, governments could consider extending the measures they have introduced in the first phase of the crisis in order to boost cash flow. In a period of financial constraints, these measures could be key in stimulating long-term investments and ensuring businesses viability. Tax payments that have been deferred in Phase 1 could be deferred further or, even, subsequently cancelled. However, one would have to anticipate the potential undesirable consequences linked to the cancellation of tax payments, given that businesses with high tax liability would be favoured over others.

Second, income support schemes for workers could be further extended. Indeed, the abrupt ending of these measures could put businesses and employees at risk whereas a more gradual tapering-out of these measures under Phase 2 could help the transition towards a long-term recovery. Although some businesses might have different needs in terms of support measures, differentiated schemes are likely to be difficult to implement and, potentially, discriminatory. From a tax perspective, different options could be considered, including holidays from payroll taxes and employer's national insurance contributions. Claw-back mechanisms could be introduced in order to discourage businesses from laying off employees once the tax incentive has been withdrawn.

Third, VAT rates could be temporarily lowered. Such measures would lead to higher consumption levels if the reduced tax rates are passed on to consumers, which is unclear and uncertain. If the tax cut is passed on, these higher levels in consumption during Phase 2 could eventually be reversed to lower consumption levels once the normal VAT rates have been reintroduced. If the tax cut is not passed on, the measure would provide cash flow to businesses, which would be similar to the effects of the first measures analysed above.

\footnotetext{
${ }^{28}$ See, for example, the UK guidance, HMRC approach to UK Permanent Establishment in response to COVID-19 pandemic, International Manual, INTM 261010 (5 May 2016), available at https://www.gov.uk/hmrc-internal-manuals/internationalmanual/intm261010 (accessed 1 May 2020) and UK guidance, HMRC approach to UK Company Residence in response to COVID-19 Pandemic, International Manual, INTM 120185, available at https://www.gov.uk/hmrc-internalmanuals/international-manual/intm120185 (accessed 1 May 2020).

${ }^{29}$ This section is based on the work of Devereux et al., supra n. 20.
} 
Fourth, countries could use corporate tax incentives, primarily to reduce the cost of capital and boost long term investments. The precise effects of such measures are hard to predict due to the large uncertainty that is expected to remain during the second phase of the crisis.

\section{Phase 3: Long-term}

Although it is too early to know when the first and second phases of the crisis will end, many proposals have already been made to generate additional revenues in the longer term, in part to pay for the costs of the crisis. Some proposals are for one-off taxes, others are for permanent taxes. Some taxes, such as wealth taxes and digital services taxes, have been proposed in both forms. Most proposals made for the longer term have been recycled from similar proposals made in the past. Time will tell if the crisis will bring about a change in environment that allows for their successful adoption in the future. This section sets out some of these proposals and their rationale. Particular attention is given to proposals for a windfall tax on business profits. ${ }^{30}$

A windfall tax on companies which have benefited the most from the crisis could take a number of different forms. Such a tax could be narrow and sector specific. For example, it could include a small number of digital giants that have done particularly well from the crisis and have been in the crosshairs of tax policy makers for some time. ${ }^{31} \mathrm{~A}$ windfall tax could alternatively be designed to apply broadly and include all the businesses that were allowed or able to trade during the lockdown. Saez and Zucman, for example, advocate an "excess profit taxes". ${ }^{32}$ The tax proposals in favour of windfall taxes often start from the observation that most economic actors have suffered from the crisis, which would justify the imposition of a tax on the few actors that have been better off during the crisis in order to "rebalance" the economy. According to Avi-Yonah: "As the nation and world undergoes the coronavirus crisis, it is unconscionable that some corporations would profit while everyone else suffers". ${ }^{33}$ Moreover, these taxes would be justified on the basis that successful businesses would never have been as successful under normal circumstances: they have benefited from the fact that many other businesses could not operate during the crisis. One-time, ex-post, windfall taxes also have the benefit of being non-distortive and thus economically efficient. ${ }^{34}$ One would caution that if the case for a one-off, ex-post excess profits tax is based on its efficiency properties rather than fairness,

\footnotetext{
${ }^{30}$ The other tax proposals are analysed more briefly given that the arguments in favour or against these proposals do not appear to be significantly different as a result of the crisis.

${ }^{31}$ For example, the UK National Union of Journalists called for a "windfall tax of 6 per cent on the tech giants, using the Digital Service Tax, towards funding a News Recovery Plan. See National Union of Journalists, NUJ launches News Recovery Plan, (16 April 2020), available at https://www.nuj.org.uk/news/nuj-launches-news-recovery-plan/ (accessed 1 May 2020). See also J. Waterson, Call for windfall tax on tech firms to help UK Newspapers survive, The Guardian, (17 April 2020), available at https://www.theguardian.com/media/2020/apr/17/call-for-windfall-tax-on-tech-firms-to-help-uk-newspapers-survive (accessed 1 May 2020).

32 E. Saez \& G. Zucman, Opinion: Jobs aren't Being Destroyed This Fast Elsewhere. Why Is That?, The New York Times (30 March 2020), available at https://www.nytimes.com/2020/03/30/opinion/coronavirus-economy-saez-zucman.html (accessed 1 May 2020). According to Saez and Zucman, "these taxes all had one goal - making sure that no one could benefit outrageously from a situation in which the masses suffered". See also A. Christians \& T. Diniz Magalhaes, "It's Time for Pillar 3: A Global Excess Profits Tax for COVID-19 and Beyond", Tax Notes (1 May 2020).

33 R. Avi-Yonah, It's Time to Revive the Excess Profits Tax, (27 March 2020), available at https://prospect.org/coronavirus/itstime-to-revive-the-excess-profits-tax/ (accessed 1 May 2020).

${ }^{34}$ Proposals for taxes on excess profits have thus far been put forward at a general level. It is not always clear whether they would all apply ex post.
} 
then one should be confident in its revenue raising ability. If not, this tax would primarily be a political gesture.

Arguments can also be made against the adoption of such taxes. First, while some businesses benefited from the lockdown, their services also facilitated the adoption of, and compliance with, the lockdown. For example, life under lockdown would have been unquestionably harder if the services of online retailers had not been available. Second, designing windfall taxes on digital companies - notable examples of which seem to have done very well out of the crisis ${ }^{35}$ - is beset by difficulties. ${ }^{36}$ How would the excess profit earned by a multinational digital company in a particular country be computed? These difficulties could be circumvented by adopting cruder taxes, including taxes on the revenues of such businesses. But this would be troubling from a tax policy perspective. Taxes on revenues are a poor proxy for taxes on excess profits. Moreover, what would the limit on such ex post taxes be? If multiple countries adopted such taxes it could lead to a free-for-all which, if nothing else, would almost certainly elicit a strong political response from the US, where many of these companies are based, not to mention appreciable risks of double- (or worse) taxation.

As mentioned above, wealth taxes have been proposed as permanent ${ }^{37}$ and one-off measures. ${ }^{38}$ The rationale for a one-off wealth tax is based on the observation that wealthy individuals have not suffered from the crisis as much as others and, in some circumstances, have even benefited from the crisis. Under these circumstances, taxing the wealthy is described as both efficient and socially fair. According to Landais, Saez and Zucman, a progressive wealth tax would be the best solution to cover the costs of the pandemic because the "most vulnerable have been hit disproportionately by the lockdown, as most high-income earners can still work from home and the wealthy can use their wealth to weather the shock better". ${ }^{39}$ Other authors have proposed variants to Landais, Saez and Zucman's proposals. For example, Insalaco and Schaanning suggested the idea of an EU-wide universal wealth

\footnotetext{
${ }^{35}$ But see D. Lee, Amazon warns coronavirus costs threaten to wipe out surging sales, Financial Times (1 May 2020), available at $h t t p s: / / w w w . f t . c o m / c o n t e n t / 4 d c 9 b 8 f c-56 f 5-47 c a-b 468-a 9 a 2 a f c 2 e c 7 b$ (accessed 1 May 2020).

${ }^{36}$ On the role of the taxation of the digitalised economy in a post-crisis environment, see University of Virginia, Tax Scholars Join Coalition Finding Solution to Pandemic-Induces State Financial Crises, https://www.law.virginia.edu/news/202004/taxscholars-collaborate-solutions-states-financial-crises-due-pandemic (accessed 1 May 2020) (where Ruth Mason is reported to have said that "if ever there was a time for digital services taxes, this is it"). See OECD, Tax and Fiscal Policy in Response to the Coronavirus Crisis, supra n. 5: "In a post-crisis environment, it is likely that addressing the tax challenges of the digitalisation of the economy and ensuring that MNEs pay a minimum level of tax (Pillar 2) will become more prominent.

${ }^{37}$ Such tax proposals have been discussed well before the crisis, such as during campaign of Democrat candidates, Elizabeth Warren and Bernie Sanders. See B. Greeley, The wealth tax plan worrying US billionaires, Financial Times (11 November 2019), available at https://www.ft.com/content/0bab153a-026b-11ea-b7bc-f3fa4e77dd47 (accessed 1 May 2020). For an overview of the main arguments in favour and against wealth taxes, see E. Saez \& G. Zucman, Progressive Wealth Taxation, BPEA Conference Draft, Brookings Papers on Economic Activity, (2019) available at https://www.brookings.edu/wpcontent/uploads/2019/09/Saez-Zucman conference-draft.pdf (accessed 1 May 2020).

38 See C. Landais, E. Saez and G. Zucman, A progressive European wealth tax to fund the European COVID response, VOX, CEPR Policy Portal (3 April 2020), available at https://voxeu.org/article/progressive-european-wealth-tax-fund-europeancovid-response (accessed 1 May 2020). The FT editorial board, Virus lays bare the frailty of the social contract. Radical reforms are required to forge a society that will work for all, Financial Times (3 April 2020), available at https://www.ft.com/content/7eff769a-74dd-11ea-95fe-fcd274e920ca (accessed 1 May 2020): "Policies until recently considered eccentric, such as basic income and wealth taxes, will have to be in the mix". See also E. Conway, Has the time come for a one-off wealth tax?, the Times (UK), (23 April 2020), available at https://www.thetimes.co.uk/article/has-thetime-come-for-a-one-off-wealth-tax-mrt3bqs8m (accessed 1 May 2020); R. Partington, John McDonnell calls for wealth tax to pay for coronavirus measures, The Guardian, (3 April 2020), available at https://www.theguardian.com/politics/2020/apr/03/john-mcdonnell-calls-for-wealth-tax-to-pay-for-coronavirus-measures (accessed 1 May 2020).

39 Landais, Saez and Zucman, supra n. 38.
} 
tax on financial assets that would "primarily be borne by financially well-off investors" ${ }^{40}$ whereas Gros argued in favour of a "one-time EU-wide levy on financial assets". ${ }^{41}$

A final category of proposals is to tax environmental negative externalities. There is a wide consensus among economists on the positive role of these taxes ${ }^{42}$ and both the OECD and the IMF Fiscal Affairs Department have suggested that carbon taxes might form part of the recovery plan adopted by countries. ${ }^{43}$ According to the IMF Fiscal Affairs Department, such a "green" recovery" is essential "to prevent one crisis leading to another". ${ }^{44}$ Arguably, the crisis makes citizens more aware of the need to tackle environmental issues, as the potential consequences of a climate crisis could be similar - or potentially even more significant - in their scope and severity to those seen in the COVID-19 pandemic.

\section{COVID-19 and International Business Taxation}

As noted in the Introduction, the COVID-19 crisis comes at a critical time in the history of international business taxation when there is significant pressure for change. In that context, this section first discusses a number of issues created by the crisis which impact elements of the existing international tax system. As the crisis, hopefully, will come to an end in the near future, these issues may be thought to be of somewhat fleeting importance. However, they are arguably of broader interest as they concern some of the more problematic areas in the existing tax system. ${ }^{45}$ In any event, the issues discussed here may be of longer-lasting concern if the changes in business practices and/or the changes in the economic environment which causes them are themselves long-lasting. The section then turns to the on-going process of international tax reform and reflects on how the crisis may affect it.

\section{The impact of the COVID-19 crisis on the operation of the existing international tax system}

\section{Operation of tax treaties}

As noted in Section 1, the OECD has already acted to provide guidance on the impact of the COVID-19 crisis on the operation of double tax treaties. Some tax authorities have similarly also issued guidance in this area. As discussed earlier, the thrust of the OECD guidance is to support the continued operation of treaties on the basis of no or little impact from the crisis. This is on the assumption that the COVID19 situation will not last long enough to cause any material effects on the operation of double tax

\footnotetext{
40 G. Insalaco and E. Schaanning, "European Corona Solidarity Bonds, (2 April 2020), available at https://papers.ssrn.com/sol3/papers.cfm?abstract id=3567382 (accessed 1 May 2020).

41 D. Gros, "A corona financial solidarity levy", VOX, CEPR Policy Portal, (22 April 2020), available at https://voxeu.org/article/corona-financial-solidarity-levy (accessed 1 May 2020)

${ }^{42}$ Among others, see D. Fullerton, A. Leicester and S. Smith, Environmental taxes, in: Dimensions of Tax Design (J. Mirrlees et al. eds., OUP 2010), available at https://www.ifs.org.uk/uploads/mirrleesreview/dimensions/ch5.pdf (accessed 1 May 2020); J. Mirrlees et al., Tax by design, Chapter 10: Environmental taxation, (13 September 2011), available at https://www.ifs.org.uk/uploads/mirrleesreview/design/ch10.pdf (accessed 1 May 2020). See also G. E. Metcalf, Paying for Pollution. Why a Carbon Tax is Good for America (OUP 2019).

${ }^{43}$ The IMF Fiscal Affairs Department issued one note on this topic in April 2020: IMF, Fiscal Affairs Department, Greening the Recovery, supra n. 16. See also OECD, Tax and Fiscal Policy in Response to the Coronavirus Crisis, supra n. 5, p. 42.

${ }_{44}^{4}$ IMF, Fiscal Affairs Department, Greening the Recovery, supra n. 16.

$45 \mathrm{It}$ is also true that the primary relevance of the COVID-19 crisis here is its impact as a financial shock or economic crisis. Sadly, history is littered with financial crises and it is also only just over ten years since the last "unprecedented" global financial crises, the subprime catastrophe. Any tax lessons gleaned from financial crises may therefore have a broader relevance.
} 
treaties, such as (and by virtue of the mobility of people issue) giving rise to the inadvertent creation of a "home office" permanent establishment (PE), triggering the dependent agency PE rule, or altering the place of effective management of a company and thereby altering its residence status for the purposes of a double tax treaty. ${ }^{46}$

However, notwithstanding this clarification from the OECD of the minimal impact from COVID-19 on the operation of double tax treaties, there may yet be a more significant impact. There is at the time of writing some possibility that the COVID-19 crisis will continue for longer than seems generally to be assumed by those producing the guidance referred to. However, leaving this point aside, it may be that, despite the OECD view, individual tax authorities adopt different positions on these issues. There is already some indication of this with tax authorities like the UK HMRC (and though adopting a generally sympathetic position in relation to the disruption) taking a "facts and circumstances" view of the consequences of the immobility issues whilst other tax authorities, such as the Australian Tax Office, have ruled out applying compliance resources to determine if central management and control is exercised in Australia because of the impacts of COVID-19. Other states, such as Jersey and Luxembourg, have positively relaxed their normal substance requirements or enacted regulations to facilitate virtual meetings. ${ }^{47}$ Another possibility is that attitudes within a tax authority shift or harden as we move through the current phase of finding ways to cope with the crisis to a phase where the overwhelming focus is on how to pay for it.

It is also possible (and in fact seems quite probable) that the experience of the COVID-19 crisis will lead to some changes in business practice that may be relevant in this context. With the development of new communication systems and adoption of new practices during the COVID-19 crisis, including the materially greater use of video conferencing, it is debatable whether there will be a full return to previous business practices. For example, it seems likely that we will instead see less business travel and more video conferencing. This may have immediate and enduring implications for board meetings where the big-picture strategic decisions are made and, at the next level down, executive committee meetings and the like, where the critical day to day business decisions are made. The result is likely to be the creation of more practical difficulties for MNEs in maintaining some of the existing disciplines relating to travel and physical attendance at meetings to support desired tax outcomes. This is especially relevant in the case of the more senior people in the organisation and in the case of the fora in which critical business decisions are taken. That of course means that any tax issues created would normally be significant, given these factors routinely determine the residence status of companies and the geographical locations to which business profits are to be attributed. There are also corresponding difficulties created for tax administrations, for example in identifying any relevant changes and assessing their impact in terms of required filings and pricing or profit adjustments. Accordingly, it seems likely that these current developments may introduce a number of enduring tax risk management and tax compliance challenges.

\footnotetext{
${ }^{46}$ The immobility of people issue could also have other implications, such as impacting the application of residence tests of a company for treaty purposes where the test is determined by the geographical location of, for example, the "central management and control" of the company.

${ }^{47}$ See A. Greenbank, G. Price, R. Kinghall, Corporate residence in the light of COVID-19, Macfarlanes, (26 March 2020) available at https://www.macfarlanes.com/what-we-think/in-depth/2020/corporate-residence-in-light-of-covid-19/ (accessed 1 May 2020). See also Jersey, Economic substance for companies, Corona virus (COVID-19) and economic substance, available at https://www.gov.je/TaxesMoney/IncomeTax/Companies/Guidelines/Pages/EconomicSubstanceForCompanies.aspx\#ancho r-3 (accessed 1 May 2020).
} 
It is worth noting that "mobility" issues have from a policy perspective long been regarded by some commentators as a source of problems in the current international tax system, for example in relation to the ease with which profits might be shifted within a MNE group by transferring intellectual property or capital and risks, etc. to group entities in low-tax jurisdictions. The "immobility" issues referred to here arguably represent a related set of issues given that they emphasise the significance to the existing international tax system of the geographical location of the key decision-makers within the business, ${ }^{48}$ though the present discussion also underlines the tax risk issues and compliance difficulties that arise in the event of sudden changes in the business environment.

\section{Income allocation and the ALP}

The COVID-19 crisis brings a number of fundamental challenges to the operation of the existing income allocation system, namely the transfer pricing and profit attribution rules. ${ }^{49}$ These challenges concern both the immediate impact and consequences of the crisis on existing transfer pricing arrangements as well as its aftermath (which seems likely to involve a global economic recession).

The COVID-19 crisis raises numerous immediate questions relating to the operation of the transfer pricing rules. For example, does the normal assumption that limited risk entities should derive stable profits remain valid in light of the crisis? Should royalties and service payments still be made, particularly if the payor is in financial difficulty? Where within the group should shut down or conversion or restructuring costs be borne? How should government support or subsidies be treated and might the benefits accrue to entities outside the jurisdiction in which any governmental support is received? How are internal financing arrangements affected? Should existing advanced pricing agreements (APAs) be modified or suspended ?50 $^{50}$

It is possible that a steer on some of these questions may be available by the traditional approach under the transfer pricing rules of analysing the exact nature of the risks or costs, etc. under consideration, working through the terms of the relevant contractual arrangements (including having regard to relevant force majeure or termination clauses), and applying the detailed Transfer Pricing Guidelines. ${ }^{51}$ However, such an approach may not be viable in a number of cases. ${ }^{52}$ This is because the transfer pricing/ arm's length principle (ALP) system does not readily accommodate a crisis of the sort that is now being experienced. Rather, the existing guidance on the ALP broadly assumes (and relies

\footnotetext{
${ }^{48}$ It is relevant to note that the recent work on the BEPS project, particularly in the increased emphasis it assigns to functional activity in the analysis of what it refers to as the "value creation" process, has reinforced the role of the key decision makers within a business for the purposes of the income allocation rules.

49 The discussion here focuses largely on the transfer pricing issues given they are in practice of greater significance.

50 In addition to these (and many other similar) questions, there will also be concerns on the part of the tax authorities that transfer pricing arrangements might in the current environment give rise to BEPS opportunities or lead to some MNEs gaming the tax rules for dealing with losses.

${ }^{51}$ The OECD is responsible for OECD, Transfer Pricing Guidelines for Multinational Enterprises and Tax Administrations (OECD Publishing 2017), which are updated periodically. The United Nations has also played a significant role in providing guidance on the ALP, as reflected in UN, Practical Manual on Transfer Pricing for Developing Countries, (UN 2017).

52 To take a simple example, if an intra group service is provided by one company to its associate and the "benefit test" as discussed in OECD, Transfer Pricing Guidelines for Multinational Enterprises and Tax Administrations (OECD Publishing 2017), section B.1.1 of Chapter VII of the OECD's Transfer Pricing Guidelines is satisfied, it might conventionally be thought that full payment for the service should be made given that the profitability of the payor normally is irrelevant to the requirement under transfer pricing rules for the payment to be made. In many current situations, however, the viability of that logic is being queried as a result of the financial impacts of the crisis.
} 
on) a functioning market as providing a yardstick for its operation. In the absence of such a functioning free market (for example in the context of a market where survival rather than profits is the immediate goal) it becomes increasingly difficult to apply the established guidance on the ALP. In place of observable financial data, there may be, at best, no more guide available than what may be gleaned from (some) observable behaviours..$^{53}$

It will also be difficult to apply any blanket treatment of the issues (such as generally-applied adjustments to existing transfer pricing practices) given the differences in the impact of the crisis - and the intended policy response - from country to country and business sector to business sector. What this means in practice is that many, if not most, of the affected cases will probably need to be addressed applying judgements based on the individual facts and circumstances in any particular case. This will likely require a huge administrative effort and commitment of resources on the part of taxpayers and tax authorities alike.

There are some aspects of the normal transfer pricing rules and practices that will self-evidently be impacted by the crisis (for example, the wider reliability of 2020 financial data). Here, the need will be for practical work-rounds or adjustments. However, there are arguably also some wider implications for how we understand and interpret the ALP itself. For example, in the relatively recent work of the OECD on how we should deal with risk in transfer pricing arrangements ${ }^{54}$ it is assumed that risk is allocable to discrete entities, with the transfer pricing treatment determined by the location in which the "control" of risk is functionally discharged. However, what may be observed in the current response to the crisis by businesses is arguably a reflection of a much greater sharing of risks across entities, potentially altering what we might construe as being at arm's length. Similarly, the interactions in the crisis between some unrelated parties (such as third-party distributors and MNE manufacturers or in franchise models between third party franchisees and MNE franchisors) have involved various financial support arrangements driven by the commercial inter-dependencies that exist in these cases. Some of these arrangements are of a sort that would hitherto have seemed most unlikely ever to be accepted as at arm's length had they been entered into by related parties. These issues raise the question of whether and how we interpret the crisis as informing our understanding of the nature of the ALP. That may well turn on whether the crisis is perceived as some unique and unprecedented event with limited wider systemic implications, or whether it has a broader relevance which includes a reassessment of the range of behaviours and arrangements that fall within the bounds of the ALP.

\section{Internationally coordinated approaches}

In normal circumstances, issues such as those discussed above relating to the operation of tax treaties or to the operation of the ALP, would be addressed on a multilateral or internationally coordinated basis. However, it is evident from the earlier discussion of the tax response to COVID-19 that the response has by any measure been extensive, but overwhelmingly discharged on a domestic or state by state basis. Nonetheless, there have been some calls for multilateral, or at least internationally coordinated, responses. These calls are typically motivated by the wish to avoid double taxation and

\footnotetext{
53 Financial data from the current period is unlikely to become available till late 2021.

${ }^{54}$ See the extensive discussion of risk, including the newly introduced six step risk framework, in OECD, Transfer Pricing Guidelines for Multinational Enterprises and Tax Administrations (OECD Publishing 2017), at paragraphs 1.56-1.106.
} 
dispute by the creation of a more consistent approach. This raises a question as to the viability of any such multilateral or coordinated actions. The nature of the uncertainties created by the crisis and the differences in the agendas and attitudes of states, as well as differences in the business sectors affected (and which in any one sector might also vary from one state to another) may make any internationally coordinated difficult.

It is possible that such coordinated actions might be more feasible in, for example, clarifying the impact of the COVID-19 crisis on the interpretation of the ALP given that the ALP standard is very widely applied across the world and relies on a long-standing practice by which its practical application is clarified by the OECD. ${ }^{55}$ However, even here the difficulties should not be underestimated. Whilst clarifying the impact of the COVID-19 crisis on more practical issues such as, for example, the usefulness of 2020 financial data may be more straightforward, there are many issues which will be rather more difficult to address and on which securing consensus approaches may be more challenging.

\section{The impact of the COVID-19 crisis on the current reform debate}

The crisis has wrought extensive economic harm on countries around the world. Its impact on domestic and international politics is as yet harder to measure, but likely to be significant too. These factors could have an impact on the discussions on reforming the international business tax system currently underway in the Inclusive Framework, though it remains to be seen whether they increase or decrease the chances of a consensus-based agreement by the end of 2020. The need for tax revenues could increase some countries' willingness to coordinate, but it could also increase other countries' willingness to break ranks if they believe their individual economic interests are better served that way. The crisis may have underscored the need for international cooperation, but it may also have made cooperation more difficult as a result of recent frictions among key players such as the United States and China, but also members of the European Union. ${ }^{56}$

Beyond these general considerations, two of the central objectives driving the reform program at the Inclusive Framework have been given renewed pressure by the crisis. The first objective is that of addressing the challenges posed by the digitalisation of the economy. It is evident that many businesses in sectors that are most affected by the crisis have benefitted materially where they have a capacity to do business on-line. ${ }^{57}$ This is clearly true of solely online businesses such as Netflix and it is also demonstrated by the surge in use of video conferencing platforms such as are provided by Zoom. Other retailers with a developed on-line capability in addition to a network of shops have also been able to maintain trading at some level in comparison to businesses with no such capability at all. The COVID-19 crisis has therefore re-emphasised the benefits of a digitalised business capability and it seems likely that this will lead to the acceleration of new digitized business models (including a shift in delivery channels from physical outlets to digital interfaces) on a global scale.

\footnotetext{
55 The work of the United Nations on the ALP is also important, particularly in the context of the ALP and developing countries. 56 In support of more European coordination, see F. Vanistendael et al., Op-Ed: European Solidarity Requires EU Taxes, (21 April 2020), https://eulawlive.com/op-ed-european-solidarity-requires-eu-taxes/ (accessed 1 May 2020).

${ }^{57}$ There are of course some sectors, such as airline and hotel businesses, which have largely closed down due to the COVID19 virus and where an online capacity has been largely irrelevant to the continuation of business activities.
} 
An important question is how these developments affect the ongoing work of the OECD and the Inclusive Framework on the digitalization of business. Immediately prior to the onset of the COVID-19 pandemic, the Inclusive Framework was in the process of working through the detailed contents of the OECD's Pillar 1 and Pillar 2 proposals. For many of the delegates to the Inclusive Framework or its Steering Group body, the COVID-19 pandemic gives a completely new - and extremely urgent - set of priorities. This might suggest some suspension of work on the digitalization of business agenda in favour of the immediate COVID-related priorities. However, for the reasons suggested above, the COVID-19 crisis makes achieving a solution to the digitalization of business issues all the more critical. This is especially true for those economies that consider that, as exacerbated by the crisis, there is currently a significant amount of business interaction in its economy which, under the existing international tax system, gives it no taxing rights at all. It therefore seems unsurprising that the work on the digitalization of business seems set to continue apace, with no shift from the original 2020 timeline. This suggests that, in the absence of an agreement being reached at the Inclusive Framework, countries will continue to pursue the application of digital service taxes.

A second objective driving the current reform programme is that of addressing remaining profit shifting opportunities available to multinationals. While clearly a long-standing objective for countries, the political and public tolerance for profit shifting is further reduced in a time of crisis. This is reflected in the discussion earlier in this article of the various calls to limit government support for business in cases where companies are involved in what may be referred to broadly as tax avoidance practices. A company failing to pay its "fair share" of tax is deemed to be particularly reprehensible at a time of national crisis, and this is even more so in light of the massive financial support extended by governments to businesses. Pillar II is designed to address remaining profit shifting issues. It is thus unsurprising that the OECD has argued that the "demand for effective global implementation of the GloBE proposal under Pillar 2 will be higher" in the post-crisis environment. ${ }^{58}$

It does of course remain highly uncertain whether a consensus-based agreement will be reached by the members of the Inclusive Framework by the end of the year, and there are certainly divergent views as to whether different reform options should be pursued over those currently under discussion. ${ }^{59}$ But there can be no doubt that the COVID-19 crisis has raised the political pressure on countries to address the two main issues on that agenda: developing a solution to the digitalisation of the economy and dealing with remaining profit shifting opportunities.

\section{Conclusion}

\footnotetext{
58 OECD, Tax and Fiscal Policy in Response to the Coronavirus Crisis, supra n. 5, p. 43. See also S. Laffitte et al., International corporate taxation after COVID-19: Minimum taxation as the new normal, VOX, CEPR Policy Portal, (14 April 2020), available at https://voxeu.org/article/minimum-effective-tax-rate-global-multinational-profits (accessed 1 May 2020)

${ }^{59}$ See, among others, M. Devereux et al., The OECD Global Anti-Base Erosion Proposal, Oxford University Centre for Business Taxation Report, (January 2020), available at https://www.sbs.ox.ac.uk/sites/default/files/202002/OECD GloBE proposal report 2020.pdf (accessed 1 May 2020); J. Englisch and J. Becker, International effective minimum taxation - the GLOBE proposal 11 World Tax Journal 4 (2019); and J. Hey, Global Minimum Taxation (GLoBE): A new stance of the OECD on tax competition and national sovereignty?, Working Paper presented at the University of Florida Tax Colloquium series (2020). More generally, see, for example, M. Devereux and J. Vella, Implications of digitalisation for international corporate tax reform in: Digital Revolutions in Public Finance, (S. Gupta, et al., eds., International Monetary Fund 2017) and M. Devereux, A. Auerbach, M. Keen, P. Oosterhuis, W. Schön and J Vella, Taxing Profit in a Global Economy, Oxford University Press (forthcoming).
} 
We have in the preceding discussion presented our preliminary assessment of the tax response to the COVID-19 crisis, taking account of the various phases of that response and the wider implications for the international tax system and its immediate priorities.

There is a clear consensus that, on a global scale, tax is highly relevant to the crisis. A wide variety of tax policy options are available to address the different phases of the crisis and we have in this article outlined the main categories of the possible responses. Unsurprisingly, the tax responses in the first phase of the crisis have largely been implemented on a purely domestic basis, reflecting different policies and priorities from state to state.

As has been discussed, the crisis also raises issues that potentially affect elements of the international tax system. Some guidance on the operation of tax treaties in the light of the COVID-19 crisis has already been issued by the OECD and certain countries. Other issues remain to be addressed. Further, the crisis comes at a critical time for the international tax system, and in particular at a time when there is significant pressure for fundamental systemic change. In that regard, the COVID-19 crisis adds significant impetus to the focus on the two central themes of the ongoing work of the Inclusive Framework on the digitalisation of business, namely the development of a solution to address the digitalisation issue (Pillar 1 ) and the closing of remaining avoidance opportunities (Pillar 2).

There will no doubt be other issues that will emerge and present additional challenges to prevailing standards and policies (such as, for example, the implications of new tracking systems and their interaction with prevailing privacy standards and relevance to tax disputes). In all likelihood, the impact and relevance of the COVID-19 crisis to the tax agenda will remain an important issue for some time to come, particularly as the full effects of the crisis will take years to play out. 


\section{Oxford University Centre for Business Taxation Working Paper series recent papers}

WP20/01 Richard Collier, Alice Pirlot and John Vella Tax policy and the COVID-19 crisis WP19/16 Alice Pirlot Don't blame it on WTO law: An analysis of the alleged WTO law incompatibility of Destination-Based Taxes

WP19/15 Irem Güçeri and Maciej Albinowski Investment Responses to Tax Policy under Uncertainty

WP19/14 David R. Agrawal and David E. Wildasin Technology and Tax Systems

WP19/13 Alice Pirlot Exploring the Impact of European Union Law on Energy and Environmental Taxation

WP19/12 Michael Devereux How should business profit be taxed? Some thoughts on conceptual developments during the lifetime of the IFS

WP19/11 Sarah Clifford and Panos Mavrokonstantis Tax Enforcement using a Hybrid between Self- and Third-Party Reporting

WP19/10 Miguel Almunia, Irem Guceri, Ben Lockwood, Kimberley Scharf More giving or more givers? The effects of tax incentives on charitable donations in the UK

WP19/09 Itai Grinberg Stabilizing "pillar one" corporate profit reallocation in an uncertain environment

WP19/08 Joel Slemrod, Obeid Ur Rehman, Mazhar Waseem Pecuniary and non-pecuniary motivations for tax compliance: evidence from Pakistan

WP19/07 Enda Hargaden, Barra Roantree Does statutory incidence matter? Earnings responses to social security contributions

WP19/06 Lucie Gadenne, Tushar K. Nandi, Roland Rathelot Taxation and supplier networks: evidence from India

WP19/05 Thiess Buettner, Boryana Madzharova Unit sales and price effects of preannounced consumption tax reforms: micro-level evidence from European VAT

WP19/04 Katarzyna Bilicka, Yaxuan Qi, Jing Xing Debt reallocation in multinational firms: evidence from the UK worldwide debt cap

WP19/03 Reuven Avi-Yonah, Orli Avi-Yonah, Nir Fishbien and Haiyan Xu Bridging the redblue divide: a proposal for US Regional Tax Relief 
WP19/02 Elizabeth Gugl, George R. Zodrow Tax competition and the efficiency of "benefitrelated" business taxes

WP19/01 Michael P Devereux, Alan Auerbach, Michael Keen, Paul Oosterhuis, Wolfgang Schön and John Vella Residual profit allocation by income

WP18/22 Ronny Freier, Martin Simmler and Christian Wittrock Public good provision, commuting and local employment

WP18/21 Christian Wittrock Localization Economies and the Sensitivity of Firm Foundations to Changes in Taxation and Public Expenditures

WP18/20 Nadine Riedel, Martin Simmler and Christian Wittrock Local fiscal policies and their impact on the number and spatial distribution of new firms

WP18/19 Leonie Hug and Martin Simmler How cost-effective is public R\&D in stimulating firm innovation?

WP18/18 Wiji Arulampalam and Andrea Papini Tax Progressivity and Self-Employment Dynamics

WP18/17 Wiji Arulampalam, Michael P Devereux and Federica Liberini Taxes and the Location of Targets

WP18/16 Frank M Fossen, Ray Rees, Davud Rostam-Afschaf and Viktor Steiner How do Entrepreneurial Portfolios Respond to Income Taxation

WP18/15 Sebastian Beer, Ruud de Mooij and Li Liu International Corporate Tax Avoidance: A Review of the Channels, Magnitudes and Blind Spots

WP18/14 Daisy Ogembo Are Presumptive Taxes a Good Option for Taxing Self-Employed Professionals in Developing Countries

WP18/13 Ilan Benshalom The Rise of Inequality and the fall of Tax Equity

WP18/12 Thomas Torslov, Ludwig Weir and Gabriel Zucman The Missing Profits of Nations

WP18/11 Andrea Lassman and Benedikt Zoller-Rydzek Decomposing the Margins of Transfer Pricing

WP18/10 Travis Chow, Jeffrey L Hoopes and Edward L Maydew US Firms on Foreign (tax) Holidays

WP18/09 Claudio Agostini, Juan Pablo Atal and Andrea Repetto Firms Response to Tax Enforcement through Audits 
WP18/08 Mazhar Waseem Information, Asymmetric Incentives or Withholding? Understanding the Self-Enforcement of Value-Added-Tax

WP18/07 Matthew Smith, Danny Yagan, Owen Zidar and Eric Zwick Capitalists in the twenty-first century

WP18/06 Daniel Shaviro The new non-territorial U.S international tax system

WP18/05 Eric M Zolt Tax Treaties and Developing Countries

WP18/04 Anne Brockmeyer, Marco Hernandez, Stewart Kettle and Spencer Smith Casting a wider tax net: Experimental evidence from Costa Rica

WP18/03 Ruud de Mooij and Li Liu At a cost:the real effects of transfer pricing regulations

WP18/02 Rita de la Feria Tax fraud and the rule of law

WP18/01 Eddy Hiu Fung Tam Behavioural response to time notches in transaction tax: Evidence from stamp duty in Hong Kong and Singapore

WP17/19 Michael P. Devereux, Giorgia Maffini and Jing Xing Corporate tax incentives \& capital structure: New evidence from UK firm-level tax returns

WP17/18 Sarah Clifford Taxing Multinationals beyond borders: financial and locational responses to CFC rules

WP17/17 Dominik von Hagen and Axel Prettl Controlled foreign corporation rules and crossborder M\&A activity

WP17/16 Marie Lamensch Destination based taxation of corporate profits - preliminary findings regarding tax collection in cross-border situations

WP17/15 Li Liu Tim Schmidt-Eisenlohr and Dongxian Guo International transfer pricing and tax avoidance: Evidence from linked trade-tax statistics in the UK.

WP17/14 Katarzyna Habu How much tax do companies pay in the UK?

WP17/13 Katarzyna Habu How aggressive are foreign multinational companies in reducing their corporation tax liability?

WP17/12 Edward D. Kleinbard The right tax at the right time

WP17/11 Aaron Flaaen The role of transfer prices in profit-shifting by U.S. multinational firms: Evidence from the 2004 Homeland Investment Act

WP17/10 Ruud de Mooij and Li Liu At a cost: The real effect of transfer pricing regulations on multinational investments 
WP17/09 Wei Cui Taxation without information: The institutional foundations of modern tax collection

WP17/08 John Brooks The definitions of income

WP17/07 Michael P. Devereux and John Vella Implications of Digitalization for International Corporation Tax Reform

WP17/06 Richard Collier and Michael P. Devereux The Destination-Based Cash Flow Tax and the Double Tax Treaties

WP17/05 Li Liu Where does multinational investment go with Territorial Taxation

WP17/04 Wiji Arulampalam, Michael P Devereux and Federica Liberini Taxes and Location of Targets

WP17/03 Johannes Becker and Joachim Englisch A European Perspective on the US plans for a Destination based cash flow tax

WP17/02 Andreas Haufler, Mohammed Mardan and Dirk Schindler Double tax discrimination to attract FDI and fight profit shifting: The role of CFC rules

WP17/01 Alan Auerbach, Michael P. Devereux, Michael Keen and John Vella Destinationbased cash flow taxation

WP16/14 Anzhela Cédelle The EU Anti-Tax Avoidance Directive: A UK Perspective

WP16/13 Michael Devereux Measuring corporation tax uncertainty across countries:

Evidence from a cross-country survey

WP16/12 Andreas Haufler and Ulf Maier Regulatory competition in capital standards with selection effects among banks

WP16/11 Katarzyna Habu Are financing constraints binding for investment? Evidence from natural experiment

WP 16/10 Li Liu and Ben Lockwood VAT notches, voluntary registration and bunching: Theory and UK evidence

WP 16/09 Harry Grubert and Roseanne Altshuler Shifting the burden of taxation from the corporate to the personal level and getting the corporate tax rate down to 15 percent

WP 16/08 Margaret K McKeehan and George R Zodrow Balancing act: weighing the factors affecting the taxation of capital income in a small open economy

WP 16/07 Michael P Devereux and Li Liu Stimulating investment through incorporation 
WP 16/06 Stephen R Bond and Irem Guceri R\&D and productivity: Evidence from large UK establishments with substantial R\&D activities

WP16/05 Tobias Böhm, Nadine Riedel and Martin Simmler Large and influential: firm size and governments' corporate tax rate choice?

WP16/04 Dhammika Dharmapala The economics of corporate and business tax reform

WP 16/03 Rita de la Feria EU VAT principles as interpretative aids to EU VAT rules: the inherent paradox

WP 16/02 Irem Guceri Will the real R\&D employees please stand up? Effects of tax breaks on firm level outcomes

WP 16/01 Giorgia Maffini, Jing Xing and Michael P Devereux The impact of investment incentives: evidence from UK corporation tax returns

WP 15/33 Anzhela Cédelle Enhanced co-operation: a way forward for tax harmonisation in the EU?

WP 15/32 James Mahon and Eric Zwick Do experts help firms optimise?

WP 15/31 Robin Boadway, Motohiro Sato and Jean-François Tremblay Cash-flow business taxation revisited: bankruptcy, risk aversion and asymmetric information

WP 15/30 Martin Simmler Do multinational firms invest more? On the impact of internal debt financing and transfer pricing on capital accumulation

WP 15/29 Daniel Shaviro The crossroads versus the seesaw: getting a 'fix' on recent international tax policy developments

WP 15/28 Zhonglan Dai, Douglas A Shackelford, Yue (Layla) Ying and Harold H Zhang Do companies invest more after shareholder tax cuts?

WP 15/27 Martin Ruf and Julia Schmider Who bears the cost of taxing the rich? An empirical study on CEO pay

WP 15/26 Eric Orhn The corporate investment response to the domestic production activities deduction

WP 15/25 Li Liu International taxation and MNE investment: evidence from the UK change to territoriality

WP 15/24 Edward D Kleinbard Reimagining capital income taxation 
WP 15/23 James R Hines Jr, Niklas Potrafke, Marina Riem and Christoph Schinke Inter vivos transfers of ownership in family firms

WP 15/22 Céline Azémar and Dhammika Dharmapala Tax sparing agreements, territorial tax reforms, and foreign direct investment

WP 15/21 Wei Cui A critical review of proposals for destination-based cash-flow corporate taxation as an international tax reform option

WP 15/20 Andrew Bird and Stephen A Karolyi Governance and taxes: evidence from regression discontinuity

WP 15/19 Reuven Avi-Yonah Reinventing the wheel: what we can learn from the Tax Reform Act of 1986

WP 15/18 Annette Alstadsæter, Salvador Barrios, Gaetan Nicodeme, Agnieszka Maria Skonieczna and Antonio Vezzani Patent boxes design, patents, location and local R\&D

WP 15/17 Laurent Bach Do better entrepreneurs avoid more taxes?

WP 15/16 Nadja Dwenger, Frank M Fossen and Martin Simmler From financial to real economic crisis: evidence from individual firm-bank relationships in Germany

WP 15/15 Giorgia Maffini and John Vella Evidence-based policy-making? The Commission's proposal for an FTT

WP 15/14 Clemens Fuest and Jing Xing How can a country 'graduate' from procyclical fiscal policy? Evidence from China?

WP 15/13 Richard Collier and Giorgia Maffini The UK international tax agenda for business and the impact of the OECD BEPS project

WP 15/12 Irem Guceri and Li Liu Effectiveness of fiscal incentives for R\&D: quasiexperimental evidence

WP 15/11 Irem Guceri Tax incentives and R\&D: an evaluation of the 2002 UK reform using micro data

WP 15/10 Rita de la Feria and Parintira Tanawong Surcharges and penalties in UK tax law

WP 15/09 Ernesto Crivelli, Ruud de Mooij, Michael Keen Base erosion, profit-shifting and developing countries

WP 15/08 Judith Freedman Managing tax complexity: the institutional framework for tax policy-making and oversight 
WP 15/07 Michael P Devereux, Giorgia Maffini and Jing Xing Corporate tax incentives and capital structure: empirical evidence from UK tax returns

WP 15/06 Li Liu and Ben Lockwood VAT notches

WP 15/05 Clemens Fuest and Li Liu Does ownership affect the impact of taxes on firm behaviour? Evidence from China.

WP 15/04 Michael P Devereux, Clemens Fuest and Ben Lockwood The taxation of foreign profits: a unified view

WP 15/03 Jitao Tang and Rosanne Altshuler The spillover effects of outward foreign direct investment on home countries: evidence from the United States

WP 15/02 Juan Carlos Suarez Serrato and Owen Zidar Who benefits from state corporate tax cuts? A local labour markets approach with heterogeneous firms

WP 15/01 Ronald B Davies, Julien Martin, Mathieu Parenti and Farid Toubal Knocking on Tax Haven's Door: multinational firms and transfer pricing 